Review Article

\title{
Physiological Significance of Ion Transporters and Channels in the Stomach and Pathophysiological Relevance in Gastric Cancer
}

\author{
Dumin Yuan, ${ }^{1,2}$ Zhiyuan Ma, ${ }^{3}$ Biguang Tuo, ${ }^{1,2}$ Taolang Li $\mathbb{D},{ }^{3}$ and Xuemei Liu $\mathbb{D}^{1,2}$ \\ ${ }^{1}$ Department of Gastroenterology, Affiliated Hospital of Zunyi Medical University, Zunyi, Guizhou Province, China \\ ${ }^{2}$ Digestive Disease Institute of Guizhou Province, Zunyi, Guizhou Province, China \\ ${ }^{3}$ Department of Thyroid and Breast Surgery, Affiliated Hospital of Zunyi Medical University, Zunyi, Guizhou Province, China
}

Correspondence should be addressed to Taolang Li; 0078029@sina.com and Xuemei Liu; onlyoneliuxuemei@163.com

Dumin Yuan and Zhiyuan Ma contributed equally to this work.

Received 25 October 2019; Revised 17 December 2019; Accepted 8 January 2020; Published 13 February 2020

Academic Editor: Ho Lin

Copyright (c) 2020 Dumin Yuan et al. This is an open access article distributed under the Creative Commons Attribution License, which permits unrestricted use, distribution, and reproduction in any medium, provided the original work is properly cited.

\begin{abstract}
Gastric cancer (GC) is a highly invasive and fatal malignant disease that accounts for $5.7 \%$ of new global cancer cases and is the third leading cause of cancer-related death. Acid/base homeostasis is critical for organisms because protein and enzyme function, cellular structure, and plasma membrane permeability change with $\mathrm{pH}$. Various ion transporters are expressed in normal gastric mucosal epithelial cells and regulate gastric acid secretion, ion transport, and fluid absorption, thereby stabilizing the differentiation and homeostasis of gastric mucosal epithelial cells. Ion transporter dysfunction results in disordered ion transport, mucosa barrier dysfunction, and acid/base disturbances, causing gastric acid-related diseases such as chronic atrophic gastritis (CAG) and GC. This review summarizes the physiological functions of multiple ion transporters and channels in the stomach, including $\mathrm{Cl}^{-}$channels, $\mathrm{Cl}^{-} / \mathrm{HCO}_{3}{ }^{-}$ exchangers, sodium/hydrogen exchangers (NHEs), and potassium $\left(\mathrm{K}^{+}\right)$channels, and their pathophysiological relevance in GC.
\end{abstract}

\section{Introduction}

Gastric cancer (GC) is one of the most aggressive types of cancer and a major health threat and contributor to cancerrelated death worldwide [1]. Therefore, clarification of its etiology pathogenesis is important for the identification of effective therapeutic targets for early diagnosis and prevention. According to the classic "Correa sequence," GC develops via a stepwise progression through a sequence of histopathologic changes $[2,3]$, including chronic atrophic gastritis (CAG), metaplasia, dysplasia, and eventually neoplasia [2]. Parietal cell loss is the critical and initial step necessary for GC development [4-12]. Too little acid secretion promotes excessive bacterial growth in the gastrointestinal (GI) tract, which triggers the upregulation of related inflammatory factors and leads to intragastric infection and CAG, eventually progressing to GC $[7,8]$. Additionally, loss of parietal cells results in deficiencies of a series of important mucosal growth factors, including transforming growth factor alpha (TGF- $\alpha$ ), amphiregulin, heparin-binding epidermal growth factor (HB-EGF), and sonic hedgehog, thereby causing the transduction of chief cells into spasmolytic polypeptide-expressing metaplasia (SPEM) $[9,10]$, an important precancerous lesion of GC $[11,12]$. In the normal stomach, acid secretion by parietal cells requires a functional $\mathrm{H}^{+} / \mathrm{K}^{+}$-ATPase, apical $\mathrm{Cl}^{-}$secretion, and $\mathrm{K}^{+}$recycling, as well as basolateral $\mathrm{HCO}_{3}{ }^{-}$and $\mathrm{Cl}^{-}$exchange (Figure 1(b)). Parietal cells actively pump out $\mathrm{H}^{+}$against a strong concentration gradient by the ATPdriven exchange of one $\mathrm{H}^{+}$for one $\mathrm{K}^{+}$via the enzyme $\mathrm{H}^{+}$/ $\mathrm{K}^{+}$-ATPase [13]. $\mathrm{Cl}^{-}$is extruded concurrently with $\mathrm{H}^{+}$across the luminal membrane, and these ions combine to form $\mathrm{HCl}$; this process relies on the cooperation of various ion transporters and channels in parietal cells of oxyntic mucosa [14] (Figure 1; Table 1). Moreover, gastric surface cells provide the first line of defense against acidic chambers and establish an alkaline environment near the apical cell surface to prevent acid damage to intestinal cells, the so-called "epithelial-bicarbonate barrier," which is an important structure for gastric mucosal protection. During this process, 


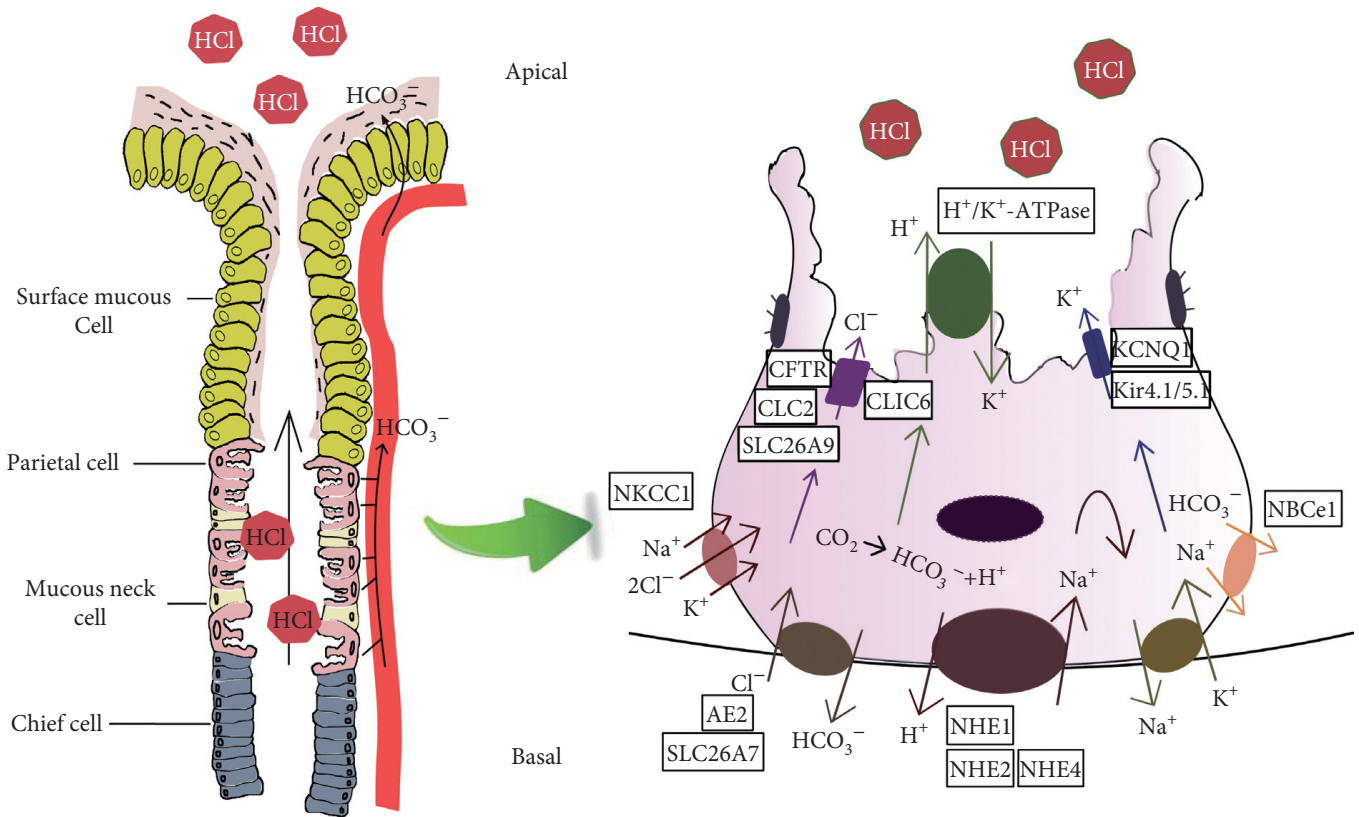

Figure 1: Ion transporters and channels related to acid/base homeostasis and their localization in parietal cells. (a) Normal structure of the oxyntic gland and acid/base homeostasis in the stomach. (b) Multiple ion transporters and channels are located in the parietal cell and are involved in the regulation of the $\mathrm{HCl}$ output; these include $\mathrm{Cl}^{-}$channels: CFTR, CLC2, CLIC6, and SLC26A9; $\mathrm{Cl}^{-} / \mathrm{HCO}_{3}{ }^{-}$exchangers: SLC26A7 and AE2; sodium/hydrogen exchangers (NHEs): NHE1, NHE2, and NHE4; potassium (K ${ }^{+}$channels: KCNQ1 and Kir4.1/5.1; the $\mathrm{Na}^{+}-\mathrm{K}^{+}-2 \mathrm{Cl}^{-}$cotransporter: $\mathrm{NKCC} 1$; the $\mathrm{Na}^{+}-\mathrm{HCO}_{3}{ }^{-}$cotransporter: $\mathrm{NBCe} 1$; and $\mathrm{H}^{+} / \mathrm{K}^{+}$-ATPase. The arrows indicate the direction of ion transport.

some ion transporters, channels, and enzymes are involved in supporting gastric bicarbonate secretion [15-18]. Taken together, these observations reveal that ion transporters and channels play an important role in regulating ion transport, mucus barrier function, signaling pathways, and acid/base homeostasis in the stomach. A previous study implicated dysfunction of the "ion transport mechanism" (ITM), which is involved in regulating GC cell proliferation, apoptosis, differentiation, and progression via different signaling pathways, in carcinogenesis [19-22]. Therefore, this review summarizes the physiological functions of different ion transporters and channels, including $\mathrm{Cl}^{-}$channels, $\mathrm{Cl}^{-} / \mathrm{HCO}_{3}{ }^{-}$exchangers, sodium/hydrogen exchangers (NHEs), and potassium $\left(\mathrm{K}^{+}\right)$channels, in parietal cells (Figure 1(b); Table 1), and their pathophysiological relevance in GC (Figure 2; Table 1) to provide new research directions to understand the molecular mechanism of this malignant disease.

\section{Physiological Characteristics of $\mathbf{C l}^{-}$ Channels in the Stomach and Pathophysiological Relevance in GC}

\subsection{Role of CFTR in GC}

2.1.1. Physiological Function of CFTR in the Stomach. CFTR is a member of the membrane transporter ATPbinding cassette $(\mathrm{ABC})$ family that comprises 48 members in humans subdivided into 7 subfamilies (ABCA-ABCG) [39]. Most ABC proteins act as active ATP-dependent transporters that couple ATP binding and hydrolysis to unidirectional transport across the matrix [40, 41]. Among human ABC proteins, CFTR is considered unique because it has no active transport function but rather acts as a phosphorylation-regulated ATP-gated anion channel [42]; it has a physiological role in transporting salt and water in epithelial cells [43] and mainly mediates the passive transport of $\mathrm{Cl}^{-}$and $\mathrm{HCO}_{3}^{-}$[44-46]. CFTR is regulated by phosphorylation [47-49] and ATP binding and hydrolysis [50-52]. It is widely expressed throughout the body but is mainly localized on the apical (cavity) membrane of ductal and ductal epithelial cells, where it is involved in transepithelial fluid and electrolyte transport and intracellular $\mathrm{pH}(\mathrm{pHi})$ regulation $[53,54]$.

CFTR is highly expressed in the apical lining of crypt epithelial cells $[55,56]$ and functions as an important regulator of intestinal homeostasis [57]. Mutations in the CFTR gene affect chloride channel function, resulting in the dysregulation of epithelial fluids and salt transport in many organs, including the lung, stomach, and intestinal digestive system, ultimately causing cystic fibrosis (CF) [58]. In the stomach, despite the detection of a low CFTR expression level $[59,60]$, the CFTR channel inhibitor CFTR-inh172 abolishes acid secretion in mice [61-63]. A potential mechanism for this effect is that CFTR may act as the ATPbinding cassette transporter associated with Kir2.1 in parietal cells to modulate $\mathrm{H}^{+}-\mathrm{K}^{+}$-ATPase-mediated secretagogue-induced acid secretion $[63,64]$.

2.1.2. Pathophysiological Role of CFTR in GC. Eberle et al. showed that brush cells in the "gastric groove" may not be 
TABLE 1: Expression, localization, and physiological and pathophysiological functions of ion transporters in the normal gastric epithelium and GC.

\begin{tabular}{|c|c|c|c|c|c|c|}
\hline Ions & $\begin{array}{l}\text { Related } \\
\text { transporters }\end{array}$ & $\begin{array}{l}\text { Human } \\
\text { gene } \\
\text { symbol }\end{array}$ & $\begin{array}{c}\text { Parietal } \\
\text { localization }\end{array}$ & $\begin{array}{c}\text { Transporter } \\
\text { type }\end{array}$ & $\begin{array}{l}\text { Physiological role in gastric } \\
\text { acid secretion }\end{array}$ & Pathophysiological relevance in GC \\
\hline \multirow{3}{*}{$\mathrm{Cl}^{-}$} & CFTR & ABCC7 & Apical & $\mathrm{O}$ & $\begin{array}{l}\text { Pumps } \mathrm{Cl}^{-} \text {out of parietal } \\
\text { cells to form } \mathrm{HCl} \text { with } \mathrm{H}^{+}\end{array}$ & $\begin{array}{l}\text { CFTR expression is upregulated in GC } \\
\text { [23] and is closely related to CA199 [24]. }\end{array}$ \\
\hline & CLC-2 & CLCN2 & Apical & $\mathrm{O}$ & $\begin{array}{l}\text { Pumps } \mathrm{Cl}^{-} \text {out of parietal } \\
\text { cells to form } \mathrm{HCl} \text { with } \mathrm{H}^{+}\end{array}$ & $\begin{array}{l}\text { Loss of CLC-2 influences acid secretion } \\
\text { and causes precancerous changes [25]. }\end{array}$ \\
\hline & CLIC-6 & CLIC6 & Apical & $\mathrm{O}$ & $\begin{array}{l}\text { Pumps } \mathrm{Cl}^{-} \text {out of parietal } \\
\text { cells to form } \mathrm{HCl} \text { with } \mathrm{H}^{+}\end{array}$ & \\
\hline \multirow[t]{3}{*}{$\mathrm{H}^{+}$} & NHE1 & SLC9A1 & Basolateral & $\mathrm{E}$ & $\begin{array}{c}\mathrm{Na}^{+}-\mathrm{H}^{+} \text {exchanger pumps } \\
\text { out redundant } \mathrm{H}^{+} \text {and } \\
\text { pumps in } \mathrm{Na}^{+} \text {at the } \\
\text { basolateral side }\end{array}$ & $\begin{array}{l}\text { NHE1 expression is upregulated in GC, } \\
\text { and functional data show that loss of } \\
\text { NHE1 inhibits GC cell proliferation, } \\
\text { migration, and invasion [26]. }\end{array}$ \\
\hline & NHE2 & SLC9A2 & Basolateral & $\mathrm{E}$ & & \\
\hline & NHE4 & SLC9A4 & Basolateral & $\mathrm{E}$ & & \\
\hline \multirow{4}{*}{$\mathrm{K}^{+}$} & KCNQ1 & KCNQ1 & Apical & $\mathrm{O}$ & Pumps $\mathrm{K}^{+}$into the lumen & $\begin{array}{c}\text { KCNQ1 is implicated in GC progression } \\
{[27,28] .}\end{array}$ \\
\hline & Kir2.2/4.1/5.1 & KIR & Apical & $\mathrm{O}$ & Pumps $\mathrm{K}^{+}$into the lumen & $\begin{array}{l}\text { Kir } 2.2 \text { plays a role in the escape of cancer } \\
\text { cells from premature senescence and in } \\
\text { tumor formation [29]. }\end{array}$ \\
\hline & $\begin{array}{c}\mathrm{Kv} 1.5 / 4.1 / \\
7.1 / 11.1\end{array}$ & $\begin{array}{c}\mathrm{KCNA} / \mathrm{D} / \\
\mathrm{Q} / \mathrm{H}\end{array}$ & Apical & $\mathrm{O}$ & Pumps $\mathrm{K}^{+}$into the lumen & $\begin{array}{c}\text { Kv1.5/4.1/7.1/11.1 promotes GC cell } \\
\text { proliferation and progression } \\
{[27,28,30-32]}\end{array}$ \\
\hline & NKCC1 & SLC12A2 & Basolateral & $\mathrm{C}$ & $\begin{array}{l}\mathrm{Na}^{+}-\mathrm{K}^{+}-2 \mathrm{Cl}^{-} \text {cotransporter } \\
\text { pumps } \mathrm{Na}^{+}, \mathrm{K}^{+} \text {, and } 2 \mathrm{Cl}^{-} \\
\text {into parietal cells }\end{array}$ & \\
\hline \multirow{3}{*}{$\mathrm{HCO}_{3}{ }^{-}$} & $\mathrm{AE} 1$ & SLC4A1 & Basolateral & $\mathrm{E}$ & $\begin{array}{c}\mathrm{Cl}^{-}-\mathrm{HCO}_{3}^{-} \text {exchanger } \\
\text { pumps } \mathrm{Cl}^{-} \text {into and } \\
\mathrm{HCO}_{3}^{-} \text {out of parietal cells }\end{array}$ & $\begin{array}{l}\text { AE1 may function as an oncogene in GC } \\
\qquad[33] .\end{array}$ \\
\hline & AE2 & SLC4A2 & Basolateral & $\mathrm{E}$ & $\begin{array}{c}\mathrm{Cl}^{-}-\mathrm{HCO}_{3}^{-} \text {exchanger } \\
\text { pumps Cl}{ }^{-} \text {into and } \\
\mathrm{HCO}_{3}^{-} \text {out of parietal cells }\end{array}$ & $\begin{array}{l}\text { The cytoplasmic AE1/p16 complex plays } \\
\text { a key role in GC progression [33-35]. }\end{array}$ \\
\hline & SLC26A7 & SLC26A7 & Basolateral & $\mathrm{C}$ & $\begin{array}{c}\mathrm{Cl}^{-}-\mathrm{HCO}_{3}^{-} \text {exchanger } \\
\text { pumps } \mathrm{Cl}^{-} \text {into and } \\
\mathrm{HCO}_{3}^{-} \text {out of parietal cells } \\
\mathrm{Na}^{+}-\mathrm{HCO}_{3}^{-} \text {cotransporter } \\
\text { pumps } \mathrm{Na}^{+} \text {and } \mathrm{HCO}_{3}^{-} \\
\text {out of parietal cells }\end{array}$ & $\begin{array}{l}\text { AE2 may play a role in carcinogenesis } \\
\qquad[36-38] .\end{array}$ \\
\hline
\end{tabular}

C: cotransporter; E: exchanger; O: orphan transporter.

the source of the alkaline solution but rather promote bicarbonate secretion and protect the gastric mucosa from gastric acid through the paracrine production of prostaglandins that activate nearby CFTR-positive cells [65]. El-Zimaity et al. investigated this issue in the stomach upon the loss of parietal cells due to Helicobacter pylori infection, which results in an inflammatory response and SPEM, another significant precancerous lesion of GC $[11,12]$. CFTR mRNA expression is upregulated under these conditions [23], suggesting that CFTR may promote GC by affecting SPEM lesions. However, later experiments showed that CFTR is closely related to classical tumor biomarker carbohydrate antigen 199 (CA199) in GC, and CFTR expression increases with age and is associated with the clinical stage of GC. Therefore, serum CFTR has a wide range of applications for GC detection [24]. Additionally, some studies have demonstrated that CFTR activity inhibition suppresses the division of the human GC cell line MKN45 [66]. Therefore, CFTR may be a new target for the prevention and treatment of GC.

\subsection{Physiological Characteristics of CLC-2 and GC}

2.2.1. Physiological Function of CLC-2 in the Stomach. CLC-2 is a widely expressed $\mathrm{Cl}^{-}$channel that can be activated by hyperpolarization, extracellular (luminal) acidic $\mathrm{pH}$, and fatty acid-activated omeprazole in rabbits and humans but not by mouse protein kinase A [67-76]. Moreover, CLC-2 can be activated by protein kinase C [77]. Secretagogue stimulation results in a major rapid morphological transformation in parietal cells, which is essential for maximal acid secretion; in this process, cytoplasmic tubulovesicles containing $\mathrm{H}^{+} / \mathrm{K}^{+}$-ATPase (and perhaps $\mathrm{Cl}^{-}$ and $\mathrm{K}^{+}$channels/transporters) fuse with the apical membrane to form a greatly expanded secretory canaliculus with 


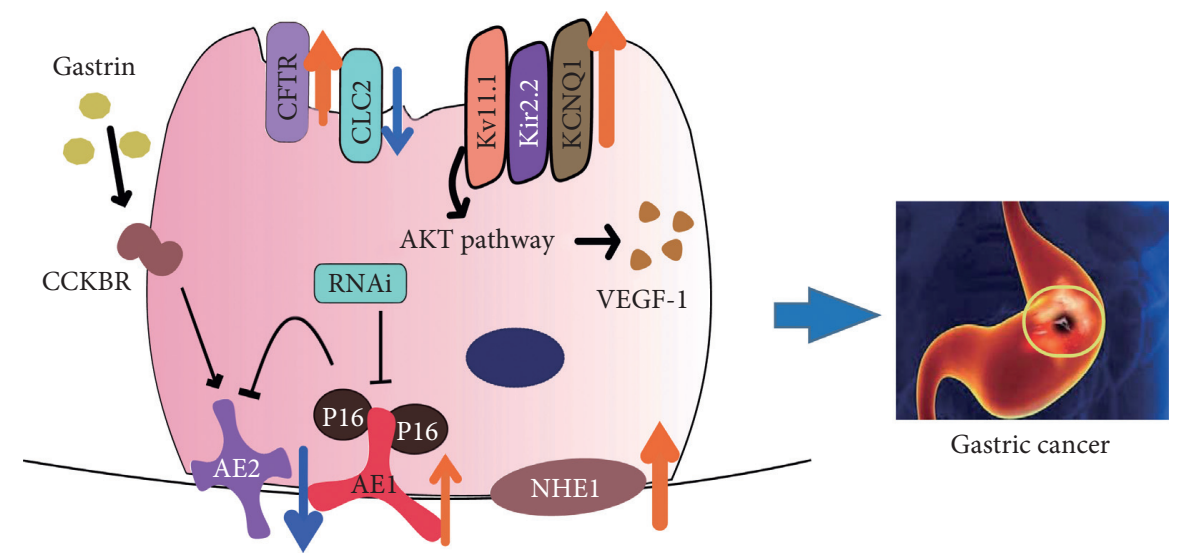

FIGURE 2: Dysfunction of ion transporters and channels in parietal cells resulting in GC onset. Upregulation of CFTR, AE1, NHE1, Kv11.1, Kir2.2, and KCNQ1, downregulation of AE2, and other interactions in parietal cells result in disorder of different signaling pathways, thereby inducing the GC onset (black arrow indicates activation; black "T" indicates inhibition; orange arrow indicates upregulation; and blue arrow indicates downregulation).

increased elongated microvilli that are recycled during the resting stage $[13,78,79]$. CLC-2 localized to gastric parietal cells in isolated rabbit gastric glands showed similar localization to $\mathrm{H}^{+} / \mathrm{K}^{+}$-ATPase and was important for gastric parietal cell acid secretion [80]. CLC-2 was detected in porcine gastric mucosa, and the CLC-2 agonist SPI-8811 was reported to rescue gastric mucosal barrier function and ameliorate acid-induced gastric injury [81]. However, other studies concluded that CLC-2 is not involved in gastric acid secretion [82]. Thus, further research is required to elucidate the function of CLC-2 in the stomach.

2.2.2. Pathophysiological Role of CLC-2 in GC. Initially, some groups investigated whether genetic ablation of CLC-2 affects the gastric mucosa with a focus on parietal cell abundance, $\mathrm{H}^{+} / \mathrm{K}^{+}$-ATPase expression, morphology, and acid secretion using CLC- $2^{+/+}$and $\mathrm{CLC}-2^{-/-}$mice. The researchers reported that CLC-2 colocalizes with $\mathrm{H}^{+} / \mathrm{K}^{+}$ATPase in gastric parietal cells. Deletion of CLC-2 resulted in a series of morphological changes in the gastric mucosa, as observed by electron microscopy: gastric gland dilation, reduced height of the gastric gland region, parietal cell loss, reduced parietal cell $\mathrm{H}^{+} / \mathrm{K}^{+}$-ATPase expression, and tubulovesicles without expanded canaliculi [25]. Thus, CLC-2 influences gastric acid secretion to a certain extent. The morphological changes in the gastric mucosa were exactly the same as the precancerous changes mentioned above. Although no relevant studies have examined the relationship between CLC-2 and GC directly, CLC-2 may play a crucial role in the maintenance of gastric mucosal homeostasis and, thus, may play a role in the development of CAG and GC.

\section{Physiological Characteristics of $\mathrm{Cl}^{-} / \mathrm{HCO}_{3}^{-}$ Exchangers in the Stomach and Pathophysiological Relevance in GC}

3.1. Physiological Function of the SLC4 Family in the Stomach. The human SLC4 family consists of 10 genes encoding secondary transporters for bicarbonate and/or carbonate
$[83,84]$. The SLC4 family is divided into three major branches: electrically neutral $\mathrm{Na}^{+}$-independent $\mathrm{Cl}^{-} / \mathrm{HCO}_{3}{ }^{-}$ antiporters, including SLC4A1 (AE1), SLC4A2 (AE2), and SLC4A3 (AE3); $\mathrm{Na}^{+}$-dependent SLC4 $\mathrm{HCO}_{3}{ }^{-}$transporters, including electricity-producing SLC4A4 (NBCe1) and SLC4A5 (NBCe2), electrically neutral $\mathrm{Na}^{+} / \mathrm{HCO}_{3}{ }^{-}$ cotransporters SLC4A7 (NBCn1) and SLC4A10 (NBCn2), and a $\mathrm{Na}^{+}-2 \mathrm{HCO}_{3}{ }^{-} / \mathrm{Cl}^{-}$exchanger; and a branch with one unusual member (SLC4A9) that has been described as being capable of most of the above actions [83, 85-87]. Here, we discuss the most significant $\mathrm{Cl}^{-} / \mathrm{HCO}_{3}{ }^{-}$antiporters, $\mathrm{AE} 1$ and AE2, in the stomach.

SLC4A1 (AE1) is the major glycoprotein of the erythrocyte membrane, with more than 1 million copies per cell [88-90]. This protein is an important member of the solute carrier SLC4 series of bicarbonate transporters [91]. The human AE1 protein is not expressed in the normal stomach [92]. The AE2 gene (also known as SLC4A2) encodes a $\mathrm{Na}^{+}$independent, electroneutral $\mathrm{Cl}^{-} / \mathrm{HCO}_{3}{ }^{-}$exchanger [93] that localizes to the membrane and is relevant for $\mathrm{pHi}$ regulation and bicarbonate secretion in several cell types. AE2 appears to primarily increase intracellular acidification since its activity is responsive to increased $\mathrm{pHi}$. In addition, AE2 regulates the intracellular chloride concentration, bicarbonate metabolism, and cell volume in a wide variety of cell types [94-96]. AE2-null mice were reported to have severe defects in acid secretion; however, morphological studies of these mice revealed abnormal gastric morphology, and most mice died around the time of weaning, making the data difficult to interpret [97]. As $\mathrm{Cl}^{-} / \mathrm{HCO}_{3}{ }^{-}$exchangers, $\mathrm{AE} 1$ and AE2 play important roles in maintaining gastric acid/ base homeostasis and secreting gastric acid.

3.2. Pathophysiological Role of the SLC4 Family in GC. Wang et al. analyzed 182 cases of advanced GC and found that AE1 expression in the cytoplasm of GC cells increased in the late stage of GC. The C-terminal 112 residues of AE1 interact with the tumor suppressor p16 [98], indicating that $\mathrm{AE} 1$ is an indicator of malignant GC [33]. Moreover, the 
cytoplasmic AE1/p16 complex enhances the stability of both proteins and plays a key role in GC progression; thus, this complex is associated with a decreased patient survival time [33-35]. Recent studies have reported that AE2 is downregulated in GC cells, and this downregulation correlates with carcinogenesis and is blocked by gastrin [36]. Recently, researchers suggested that gastrin might suppress GC cells by increasing AE2 expression and that gastrin may stimulate AE2 expression in GC cells via early growth response 1 (EGR1) in a cholecystokinin B receptor (CCKBR)-dependent manner [37], demonstrating that AE2 plays a role in carcinogenesis. Furthermore, Wu et al. reported that ectopic expression of AE2, AE1, and p16 is an important pathogenic factor in the development of GC and that dysfunctional AE2 can be degraded by a ubiquitin-dependent pathway [38]. Destruction of AE2 leads to cell alkalization and gastric acid deficiency [97], while AE1/p16 expression leads to the downregulation of AE2, which aggravates cell alkalization and gastric acid deficiency, both of which are characteristics of GC. Similarly, knockdown of AE1 expression with synthetic small interfering RNA (siRNA) significantly inhibited GC growth and reduced the tumor formation rate in a mouse GC model. In addition, the rate of GC formation at the end of the experiment decreased simultaneously with the incidence of gastric atypical hyperplasia, suggesting that AE1 RNA interference (RNAi) therapy may inhibit the formation of gastric tumors by blocking GC progression [99]. In summary, AE1 may function as a cancer-promoting gene for GC and AE2 plays a role in carcinogenesis, indicating that these proteins are potential targets for the treatment of GC.

\section{Physiological Characteristics of NHEs in the Stomach and Pathophysiological Relevance in GC}

4.1. Physiological Function of the NHE Family in the Stomach. The mammalian NHE family has 10 members, and each member has its own cellular localization and tissue distribution. NHEs have broad physiological functions, including pHi homeostasis, cell volume regulation, acid-base regulation, and electroneutral $\mathrm{NaCl}$ transport [100, 101]. Multiple NHE isoforms are expressed in the stomach; NHE1, NHE2, and NHE4 are expressed in the stomach and play important roles in gastric cell volume and $\mathrm{pHi}$ regulation [102]; thus, we will discuss NHE1, NHE2, and NHE4 in the stomach.

$\mathrm{NHE} 1$ is the most direct $\mathrm{pH}$ regulator and has become a focus of research in recent years [103]. NHE1 expression and function in the stomach have been demonstrated in healthy humans [104]. This protein determines $\mathrm{pHi}$ by catalyzing the electroneutral exchange of extracellular $\mathrm{Na}^{+}$and intracellular $\mathrm{H}^{+}$[105]. Epithelial NHE2 is encoded by the SLC9A2 gene, has 812 amino acids, and is localized on the basolateral membrane of the stomach [106, 107]. Parietal cells are missing in Slc9a2 knockout mice, consistent with the involvement of NHE2 in preventing or responding to damage [108]. NHE4 is highly expressed in the stomach, where it is localized on the basolateral membrane of parietal cells [100]. Deletion of NHE4 causes morphological changes in the gastric mucosa, including a loss of parietal cells and mature chief cells and an increase in the number of undifferentiated cells, necrotic cells, and apoptotic cells. The researchers concluded that NHE4 functionally couples with AE2 (SLC4A2) to maintain cell volume and intracellular ion concentrations for acid secretion [109]. However, the functions and molecular mechanisms of NHE1, NHE2, and NHE4 in regulating gastric cell volume and pHi are not fully understood.

4.2. Pathophysiological Role of NHEs in GC. NHE1 can determine $\mathrm{pHi}$ by transporting electroneutral extracellular $\mathrm{Na}^{+}$ and intracellular $\mathrm{H}^{+}$[105]. Some experiments have shown that NHE1 expression is higher in GC tissues and cell lines than in normal tissues and cell lines. Loss of NHE1 inhibits GC cell proliferation, migration, and invasion in vitro, and NHE1 inhibition reduces GC tumor growth in nude mice. Moreover, NHE1 regulates these events through changes in the $\mathrm{pHi}$ and the expression of corresponding genes, and modulation of NHE1 and its downstream signaling pathways could be a novel therapeutic strategy for human GC [26]. Therefore, NHE1 may be a potential target in the treatment of GC. However, more research should be performed to clarify the pathophysiological functions of NHE2 and NHE4 in GC because of their important roles in the normal stomach.

\section{Physiological Characteristics of $\mathbf{K}^{+}$ Channels in the Stomach and Pathophysiological Relevance in GC}

5.1. Role of $\mathrm{K}^{+}$Channels in the Stomach. Potassium $\left(\mathrm{K}^{+}\right)$ channels are located in cell membranes and control $\mathrm{K}^{+}$ion efflux and influx [110] to play crucial roles in both excitable and nonexcitable cells. Based on the structure, activation mechanisms, and function, $\mathrm{K}^{+}$channels are classified into four main classes: calcium-activated $\mathrm{K}^{+}(\mathrm{KCa})$ channels, voltage-gated $\mathrm{K}^{+}(\mathrm{Kv})$ channels, inward-rectifier $\mathrm{K}^{+}$(Kir) channels, and two-pore domain $\mathrm{K}^{+}(\mathrm{K} 2 \mathrm{P})$ channels. The $\mathrm{Kv}$ channel family can be subdivided into Kv1-4 channels (Shaker-, Shab-, Shaw-, and Shal-like subunits); silent Kv5, Kv6, Kv8, and Kv9 subunits (regulators); Kv7 channels (KCNQ); and Kv10-12 channels (EAG-like) [111, 112]. $\mathrm{K}^{+}$ channels influence gastric acid secretion by mediating the pumping in and out of $\mathrm{K}^{+}$and maintaining the $\mathrm{K}^{+}$concentration to help $\mathrm{H}^{+} / \mathrm{K}^{+}$-ATPases pump $\mathrm{H}^{+}$into the lumen. Multiple $\mathrm{K}^{+}$channels have been reported to be involved in gastric acid secretion, and dysfunction of $\mathrm{K}^{+}$channels leads to an imbalance in gastric mucosa ion homeostasis and impaired gastric acid secretion [113-115], which may further promote the development of CAG and GC [27-31].

5.2. Pathophysiological Function of $\mathrm{K}^{+}$Channels in GC. Numerous $\mathrm{K}^{+}$channels have been shown to play an important role in the development and progression of GC [27-31]. Deletion of Kir2.2 plays a role in the escape of 
cancer cells from premature senescence and in suppressing tumorigenesis in vivo by increasing the levels of the tumor suppressor $\mathrm{p} 27$ and ROS accumulation to inducing cellular senescence [29]. In the $\mathrm{Kv}$ channel family, Kv4.1, Kv7.1 (KCNQ1), and Kv1.5 have been identified to be involved in promoting GC cell proliferation and progression $[27,28,30,31]$. Furthermore, the KCNQ1 subunit KCNE2, which is downregulated in GC, was demonstrated to suppress cell proliferation and tumorigenesis of the stomach [116]. Additionally, although Kv11.1 was not detected in the normal stomach, Kv11.1 expression was upregulated in GC tissues [32], and Kv11.1 has been shown to enhance the proliferation and tumorigenesis of GC both in vitro and in vivo and modulate vascular endothelial growth factor 1 (VEGF-1) secretion through an AKT-dependent pathway (Figure 2) [117, 118]. Moreover, Kv11.1 has been demonstrated to be necessary for the cisplatin-mediated induction of apoptosis in GC, suggesting that this channel may be a new potential target for cisplatin chemotherapy [119]. Thus, the correction of $\mathrm{K}^{+}$channel disorders may be another effective therapeutic strategy for GC. The molecular mechanism of the dysfunction of multiple ion transporters and channels in GC onset is summarized in Figure 2.

\section{Conclusion}

Multiple ion transporters and channels in normal gastric mucosal epithelial cells regulate gastric acid secretion, ion transport, and fluid absorption and thus play an important role in maintaining acid/base homeostasis. Dysfunction of these ion transporters results in disordered ion transport, mucosa barrier dysfunction, and impaired acid/base homeostasis, leading to the development of gastric acid-related diseases, including CAG and GC. We summarize the specific localization, transport type, and function of ion transporters that are involved in acid secretion and the role their dysfunction plays in GC in Figures 1 and 2 and Table 1. Although the physiological and pathophysiological roles of these ion transporters have been described, basic and genetic research is still required to fully elucidate these functions to provide promising therapeutic targets for CAG and GC. In this review, we provide a basic and systemic description in this field to prompt researchers to focus on the functional diversity of ion transporters and channels in the stomach and their role in GC onset, which will provide a novel perspective not only for GC therapy but also for prevention.

\section{Disclosure}

Xuemei Liu and Taolang Li are the co-corresponding authors. Dumin Yuan and Zhiyuan Ma are the co-first authors.

\section{Conflicts of Interest}

The authors declare no conflicts of interest.

\section{Authors' Contributions}

D.M.Y. and Z.Y.M. viewed the literature; X.M.L. and T.L.L. conceived and designed the paper; D.M.Y. and Z.Y.M. wrote the manuscript, X.M.L., T.L.L. and B.G.T. revised this manuscript; all authors read and approved the final version.

\section{Acknowledgments}

The authors thank JXZ, GRW, HJ, and JXA, who provided us with suggestions for this paper and support for the daily experiments. This work was supported by the National Natural Science Foundation of China (No. 81560456 and 81860103 to X.M.L., 81660098 to T.L.L. and 81572438 to B.G.T.), the Outstanding Scientific Youth Fund of Guizhou Province (2017-5608 to X.M.L.), the 15851 Talent Projects of Zunyi City (to T.L.L.), and the Graduate Research Fund Project of Guizhou Province (No. YJSCXJH [2018] 064 to D.M.Y.).

\section{References}

[1] F. Bray, J. Ferlay, I. Soerjomataram, R. L. Siegel, L. A. Torre, and A. Jemal, "Global cancer statistics 2018: GLOBOCAN estimates of incidence and mortality worldwide for 36 cancers in 185 countries," CA: A Cancer Journal for Clinicians, vol. 68, no. 6, pp. 394-424, 2018.

[2] P. Correa, "A human model of gastric carcinogenesis," Cancer Research, vol. 48, no. 13, pp. 3554-3560, 1998.

[3] P. Correa, W. Haenszel, C. Cuello, S. Tannenbaum, and M. Archer, "A model for gastric cancer epidemiology," The Lancet, vol. 306, no. 7924, pp. 58-60, 1975.

[4] J. Burclaff, L. H. Osaki, D. Liu, J. R. Goldenring, and J. C. Mills, "Targeted apoptosis of parietal cells is insufficient to induce metaplasia in stomach," Gastroenterology, vol. 152, no. 4, pp. 762-766, 2017.

[5] K. T. Nam, H. J. Lee, J. F. Sousa et al., "Mature chief cells are cryptic progenitors for metaplasia in the stomach," Gastroenterology, vol. 139, no. 6, pp. 2028-2037, 2010.

[6] J. C. Mills and O. J. Sansom, "Reserve stem cells: differentiated cells reprogram to fuel repair, metaplasia, and neoplasia in the adult gastrointestinal tract," Science Signaling, vol. 8, no. 385, p. re8, 2015.

[7] J. R. Goldenring and S. Nomura, "Differentiation of the gastric mucosa III. Animal models of oxyntic atrophy and metaplasia," American Journal of Physiology-Gastrointestinal and Liver Physiology, vol. 291, no. 6, pp. G999-G1004, 2006.

[8] L. Friis-Hansen, "Achlorhydria is associated with gastric microbial overgrowth and development of cancer: lessons learned from the gastrin knockout mouse," Scandinavian Journal of Clinical and Laboratory Investigation, vol. 66, no. 7, pp. 607-621, 2006.

[9] C. Xiao, S. A. Ogle, M. A. Schumacher et al., "Loss of parietal cell expression of Sonic hedgehog induces hypergastrinemia and hyperproliferation of surface mucous cells," Gastroenterology, vol. 138, no. 2, pp. 550-561, 2010.

[10] K. T. Nam, H. J. Lee, H. Mok et al., “Amphiregulin-deficient mice develop spasmolytic polypeptide expressing metaplasia and intestinal metaplasia," Gastroenterology, vol. 136, no. 4, pp. 1288-1296, 2009.

[11] H. M. T. El-Zimaity, J. Ramchatesingh, M. Ali Saeed, and D. Y. Graham, "Gastric intestinal metaplasia: subtypes and natural history," Journal of Clinical Pathology, vol. 54, no. 9, pp. 679-683, 2001.

[12] M. I. Filipe, N. Muñoz, I. Matko et al., "Intestinal metaplasia types and the risk of gastric cancer: a cohort study in 
Slovenia," International Journal of Cancer, vol. 57, no. 3, pp. 324-329, 1994.

[13] J. G. Forte and L. Zhu, "Apical recycling of the gastric parietal cell H,K-ATPase," Annual Review of Physiology, vol. 72, no. 1, pp. 273-296, 2010.

[14] U. Seidler, P. Song, F. Xiao, B. Riederer, O. Bachmann, and $\mathrm{M}$. Chen, "Recent advances in the molecular and functional characterization of acid/base and electrolyte transporters in the basolateral membranes of gastric and duodenal epithelial cells," Acta Physiologica, vol. 201, no. 1, pp. 3-20, 2011.

[15] I. P. Pawlow, "Die arbeit der Verdauungsdrüsen," Edinburgh Medical Journal, vol. 4, no. 5, pp. 452-454, 1987.

[16] B. J. Reichstein and M. M. Cohen, "Effect of acetazolamide on rat gastric mucosal protection and stimulated bicarbonate secretion with 16,16-dimethyl PGE2," Journal of Laboratory and Clinical Medicine, vol. 104, no. 5, pp. 797-804, 1984.

[17] J. Xu, S. Barone, S. Petrovic et al., "Identification of an apical Cl-/HCO3- exchanger in gastric surface mucous and duodenal villus cells," American Journal of Physiology-Gastrointestinal and Liver Physiology, vol. 285, no. 6, pp. G1225-G1234, 2003.

[18] J. Xu, J. Henriksnäs, S. Barone et al., "SLC26A9 is expressed in gastric surface epithelial cells, mediates $\mathrm{Cl}-/ \mathrm{HCO} 3-$ exchange, and is inhibited by NH4+," American Journal of Physiology-Cell Physiology, vol. 289, no. 2, pp. C493-C505, 2005.

[19] M. B. A. Djamgoz, R. C. Coombes, and A. Schwab, "Ion transport and cancer: from initiation to metastasis," Philosophical Transactions of the Royal Society B: Biological Sciences, vol. 369, no. 1638, Article ID 20130092, 2014.

[20] J. Xie, X. Y. Zhu, L. M. Liu, and Z. Q. Meng, "Solute carrier transporters: potential targets for digestive system neoplasms," Cancer Management and Research, vol. 10, pp. 153-166, 2018.

[21] X. Zhou, W.-J. Sun, W.-M. Wang et al., "Artesunate inhibits the growth of gastric cancer cells through the mechanism of promoting oncosis both in vitro and in vivo," Anti-Cancer Drugs, vol. 24, no. 9, pp. 920-927, 2013.

[22] G. C. Zhu, L. Gao, J. He et al., "CD90 is upregulated in gastric cancer tissues and inhibits gastric cancer cell apoptosis by modulating the expression level of SPARC protein," Oncology Reports, vol. 34, no. 5, pp. 2497-2506, 2015.

[23] V. G. Weis, J. F. Sousa, B. J. LaFleur et al., "Heterogeneity in mouse spasmolytic polypeptide-expressing metaplasia lineages identifies markers of metaplastic progression," Gut, vol. 62, no. 9, pp. 1270-1279, 2013.

[24] H. Liu, W. Wu, Y. Liu, C. Zhang, and Z. Zhou, "Predictive value of cystic fibrosis transmembrane conductance regulator (CFTR) in the diagnosis of gastric cancer," Clinical and Investigative Medicine, vol. 37, no. 4, pp. E226-E232, 2014.

[25] M. P. Nighot, P. K. Nighot, T. Y. Ma et al., "Genetic ablation of the ClC-2 Cl- channel disrupts mouse gastric parietal cell acid secretion," PLoS One, vol. 10, no. 9, Article ID e0138174, 2015.

[26] R. Xie, H. Wang, H. Jin, G. Wen, B. Tuo, and J. Xu, "NHE1 is upregulated in gastric cancer and regulates gastric cancer cell proliferation, migration and invasion," Oncology Reports, vol. 37, no. 3, pp. 333-340, 2017.

[27] J. Zhang, Z. Zhao, C. Zu et al., "Atrial natriuretic peptide modulates the proliferation of human gastric cancer cells via KCNQ1 expression," Oncology Letters, vol. 6, no. 2, pp. 407-414, 2013.

[28] J. Bielanska, J. Hernandez-Losa, M. Perez-Verdaguer et al., "Voltage-dependent potassium channels Kv1.3 and Kv1.5 in human cancer," Current Cancer Drug Targets, vol. 9, no. 8, pp. 904-914, 2009.

[29] I. Lee, C. Park, and W. K. Kang, "Knockdown of inwardly rectifying potassium channel Kir2.2 suppresses tumorigenesis by inducing reactive oxygen species-mediated cellular senescence," Molecular Cancer Therapeutics, vol. 9, no. 11, pp. 2951-2959, 2010.

[30] H.-J. Kim, S. H. Jang, Y. A. Jeong, P. D. Ryu, D.-Y. Kim, and S. Y. Lee, "Involvement of Kv4.1 K+ channels in gastric cancer cell proliferation," Biological \& Pharmaceutical Bulletin, vol. 33, no. 10, pp. 1754-1757, 2010.

[31] S.-I. Liu, C.-W. Chi, W.-Y. Lui, K.-T. Mok, C.-W. Wu, and S.-N. Wu, "Correlation of hepatocyte growth factor-induced proliferation and calcium-activated potassium current in human gastric cancer cells," Biochimica et Biophysica Acta (BBA)-Biomembranes, vol. 1368, no. 2, pp. 256-266, 1998.

[32] X. W. Ding, W. B. Yang, S. Gao et al., "Prognostic significance of hERG1 expression in gastric cancer," Digestive Diseases \& Sciences, vol. 55, no. 4, pp. 1004-1010, 2010.

[33] W.-Q. Xu, L.-J. Song, Q. Liu et al., "Expression of anion exchanger 1 is associated with tumor progress in human gastric cancer," Journal of Cancer Research and Clinical Oncology, vol. 135, no. 10, pp. 1323-1330, 2009.

[34] W.-W. Shen, J. Wu, L. Cai et al., "Expression of anion exchanger 1 sequestrates 16 in the cytoplasm in gastric, colonic adenocarcinoma," Neoplasia, vol. 9, no. 10, pp. 812-819, 2007.

[35] Q. Liu, L. J. Song, W. Q. Xu et al., "Expression of cytoplasmic p16 and anion exchanger 1 is associated with the invasion and absence of lymph metastasis in gastric carcinoma," Molecular Medicine Reports, vol. 2, no. 2, pp. 169-174, 2009.

[36] Y. Yang, P. P. Wu, J. Wu et al., "Expression of anion exchanger 2 in human gastric cancer," Experimental Oncology, vol. 30, no. 1, pp. 81-87, 2008.

[37] T. Wang, L. Zhao, Y. Yang et al., "EGR1 is critical for gastrindependent upregulation of anion exchanger 2 in gastric cancer cells," FEBS Journal, vol. 280, no. 1, pp. 174-183, 2013.

[38] J. Wu, Y.-C. Zhang, W.-H. Suo et al., "Induction of anion exchanger-1 translation and its opposite roles in the carcinogenesis of gastric cancer cells and differentiation of K562 cells," Oncogene, vol. 29, no. 13, pp. 1987-1996, 2010.

[39] M. D. Parker, E. P. Ourmozdi, and M. J. A. Tanner, "Human BTR1, a new bicarbonate transporter superfamily member and human AE4 from kidney," Biochemical and Biophysical Research Communications, vol. 282, no. 5, pp. 1103-1109, 2001.

[40] M. D. Parker, R. Musa-Aziz, J. D. Rojas, I. Choi, C. M. Daly, and W. F. Boron, "Characterization of human SLC4A10 as an electroneutral $\mathrm{Na} / \mathrm{HCO} 3$ Cotransporter $(\mathrm{NBCn} 2)$ with $\mathrm{Cl}$ Self-exchange activity," Journal of Biological Chemistry, vol. 283, no. 19, pp. 12777-12788, 2008.

[41] C. Z. Wang, H. Yano, K. Nagashima, and S. Seino, "The Na+driven $\mathrm{Cl}-\mathrm{HCO} 3-$ exchanger. Cloning, tissue distribution, and functional characterization," Journal of Biological Chemistry, vol. 275, no. 45, pp. 35486-35490, 2001.

[42] J. Praetorius, L. N. Nejsum, and S. Nielsen, "A SCL4A10 gene product maps selectively to the basolateral plasma membrane of choroid plexus epithelial cells," American Journal of Physiology-Cell Physiology, vol. 286, no. 3, pp. C601-C610, 2004.

[43] V. Saint-Criq and M. A. Gray, "Role of CFTR in epithelial physiology," Cellular and Molecular Life Sciences, vol. 74, no. 1, pp. 93-115, 2017. 
[44] D. C. Gadsby, P. Vergani, and L. Csanády, "The ABC protein turned chloride channel whose failure causes cystic fibrosis," Nature, vol. 440, no. 7083, pp. 477-483, 2006.

[45] T.-C. Hwang and K. L. Kirk, "The CFTR ion channel: gating, regulation, and anion permeation," Cold Spring Harbor Perspectives in Medicine, vol. 3, no. 1, Article ID a009498, 2013.

[46] P. Linsdell, "Functional architecture of the CFTR chloride channel," Molecular Membrane Biology, vol. 31, no. 1, pp. 1-16, 2014.

[47] J. A. Tabcharani, X.-B. Chang, J. R. Riordan, and J. W. Hanrahan, "Phosphorylation-regulated CI- channel in CHO cells stably expressing the cystic fibrosis gene," Nature, vol. 352, no. 6336, pp. 628-631, 1991.

[48] S. H. Cheng, D. P. Rich, J. Marshall, R. J. Gregory, M. J. Welsh, and A. E. Smith, "Phosphorylation of the R domain by cAMP-dependent protein kinase regulates the CFTR chloride channel," Cell, vol. 66, no. 5, pp. 1027-1036, 1991.

[49] Y. Jia, C. J. Mathews, and J. W. Hanrahan, "Phosphorylation by protein kinase $\mathrm{C}$ is required for acute activation of cystic fibrosis transmembrane conductance regulator by protein kinase A," Journal of Biological Chemistry, vol. 272, no. 8, pp. 4978-4984, 1997.

[50] M. P. Anderson, H. A. Berger, D. P. Rich, R. J. Gregory, A. E. Smith, and M. J. Welsh, "Nucleoside triphosphates are required to open the CFTR chloride channel," Cell, vol. 67, no. 4, pp. 775-784, 1991.

[51] M. Anderson and M. Welsh, "Regulation by ATP and ADP of CFTR chloride channels that contain mutant nucleotidebinding domains," Science, vol. 257, no. 5077, pp. 1701-1704, 1992.

[52] T. Baukrowitz, T.-C. Hwang, A. C. Nairn, and D. C. Gadsby, "Coupling of CFTR Cl- channel gating to an ATP hydrolysis cycle," Neuron, vol. 12, no. 3, pp. 473-482, 1994.

[53] R. A. Frizzell and J. W. Hanrahan, "Physiology of epithelial chloride and fluid secretion," Cold Spring Harbor Perspectives in Medicine, vol. 2, no. 6, Article ID a009563, 2012.

[54] J. F. Collawn and M. Sadis, "CFTR and lung homeostasis," American Journal of Physiology-Lung Cellular and Molecular Physiology, vol. 307, no. 12, pp. 917-923, 2014.

[55] N. Ameen, J. Alexis, and P. Salas, "Cellular localization of the cystic fibrosis transmembrane conductance regulator in mouse intestinal tract," Histochemistry and Cell Biology, vol. 114, no. 1, pp. 69-75, 2000.

[56] A. K. Singh, M. Sjöblom, W. Zheng et al., "CFTR and its key role inin vivoresting and luminal acid-induced duodenal HCO3-secretion," Acta Physiologica, vol. 193, no. 4, pp. 357-365, 2008.

[57] B. L. N. Than, J. A. C. M. Goos, A. L. Sarver et al., "The role of KCNQ1 in mouse and human gastrointestinal cancers," Oncogene, vol. 33, no. 29, pp. 3861-3868, 2014.

[58] J. R. Riordan, J. Rommens, B. Kerem et al., "Identification of the cystic fibrosis gene: cloning and characterization of complementary DNA," Science, vol. 245, no. 4922, pp. 1066-1073, 1989.

[59] T. V. Strong, K. Boehm, and F. S. Collins, "Localization of cystic fibrosis transmembrane conductance regulator mRNA in the human gastrointestinal tract by in situ hybridization," Journal of Clinical Investigation, vol. 93, no. 1, pp. 347-354, 1994.

[60] X. Liu, T. Li, B. Riederer et al., "Loss of Slc26a9 anion transporter alters intestinal electrolyte and $\mathrm{HCO}_{3}$ - transport and reduces survival in CFTR-deficient mice," Pflügers
Archiv-European Journal of Physiology, vol. 467, no. 6, pp. 1261-1275, 2015.

[61] J. R. Thiagarajah, Y. Song, P. M. Haggie, and A. S. Verkman, "A small molecule CFTR inhibitor produces cystic fibrosislike submucosal gland fluid secretions in normal airways," The FASEB Journal, vol. 18, no. 7, pp. 875-877, 2004.

[62] A. S. Hongre, I. Baro, B. Berthon, and D. Escande, "Effects of sulphonylureas on CAMP-stimulated Cl- transport via the cystic fibrosis gene product in human epithelial cells," Pflügers Archiv: European Journal of Physiology, vol. 426, no. 3-4, pp. 284-287, 1994.

[63] S. M. Sidani, P. Kirchhoff, T. Socrates et al., " $\Delta$ F508 mutation results in impaired gastric acid secretion," Journal of Biological Chemistry, vol. 282, no. 9, pp. 6068-6074, 2007.

[64] J. P. Geibel, "Role of potassium in acid secretion," World Journal of Gastroenterology, vol. 11, no. 34, pp. 5259-5265, 2005.

[65] J. A. Eberle, K. L. Muller-Roth, P. Widmayer, V. Chubanov, T. Gudermann, and H. Breer, "Putative interaction of brush cells with bicarbonate secreting cells in the proximal corpus mucosa," Frontiers in Physiology, vol. 4, p. 182, 2013.

[66] L. Zhu, X. J. Yu, S. Xing, F. Jin, and W. J. Yang, "Involvement of AMP-activated protein kinase (AMPK) in regulation of cell membrane potential in a gastric cancer cell line," Scientific Reports, vol. 8, no. 1, p. 6028, 2018.

[67] J. Cuppoletti, A. M. Baker, and D. H. Malinowska, "Clchannels of the gastric parietal cell that are active at low $\mathrm{pH}$," American Journal of Physiology-Cell Physiology, vol. 264, no. 6, pp. C1609-C1618, 1993.

[68] S.-E. Jordt and T. J. Jentsch, "Molecular dissection of gating in the ClC-2 chloride channel," The EMBO Journal, vol. 16, no. 7, pp. 1582-1592, 1997.

[69] D. H. Malinowska, E. Y. Kupert, A. Bahinski, A. M. Sherry, and J. Cuppoletti, "Cloning, functional expression, and characterization of a PKA-activated gastric Cl- channel," American Journal of Physiology-Cell Physiology, vol. 268, no. 1, pp. C191-C200, 1995.

[70] A. M. Sherry, K. Stroffekova, L. M. Knapp, E. Y. Kupert, J. Cuppoletti, and D. H. Malinowska, "Characterization of the human $\mathrm{pH}$ - and PKA-activated $\mathrm{ClC}-2 \mathrm{G}$ (2 alpha) Clchannel," American Journal of Physiology-Cell Physiology, vol. 273, no. 2, pp. C384-C393, 1997.

[71] A. Thiemann, S. Gründer, M. Pusch, and T. J. Jentsch, "A chloride channel widely expressed in epithelial and nonepithelial cells," Nature, vol. 356, no. 6364, pp. 57-60, 1992.

[72] J. Cuppoletti, D. H. Malinowska, K. P. Tewari et al., "SPI0211 activates T84 cell chloride transport and recombinant human ClC-2 chloride currents," American Journal of Physiology-Cell Physiology, vol. 287, no. 5, pp. C1173-C1183, 2004.

[73] J. Cuppoletti, J. Chakrabarti, K. Tewari, and D. H. Malinowska, "Methadone but not morphine inhibits lubiprostone-stimulated $\mathrm{Cl}$ - currents in T84 intestinal cells and recombinant human $\mathrm{ClC}-2$, but not CFTR Cl- currents," Cell Biochemistry and Biophysics, vol. 66, no. 1, pp. 53-63, 2013.

[74] J. Cuppoletti, J. Chakrabarti, K. P. Tewari, and D. H. Malinowska, "Differentiation between human ClC-2 and CFTR Cl- channels with pharmacological agents," American Journal of Physiology-Cell Physiology, vol. 307, no. 5, pp. C479-C492, 2014.

[75] K. P. Tewari, D. H. Malinowska, A. M. Sherry, and J. Cuppoletti, "PKA and arachidonic acid activation of human recombinant ClC-2 chloride channels," American 
Journal of Physiology-Cell Physiology, vol. 279, no. 1, pp. C40-C50, 2000.

[76] J. Cuppoletti, K. P. Tewari, A. M. Sherry, E. Y. Kupert, and D. H. Malinowska, "ClC-2 Cl- channels in human lung epithelia: activation by arachidonic acid, amidation, and acid-activated omeprazole," American Journal of PhysiologyCell Physiology, vol. 281, no. 1, pp. C46-C54, 2001.

[77] M. Bali, J. Lipecka, A. Edelman, and J. Fritsch, "Regulation of ClC-2 chloride channels in T84 cells by TGF- $\alpha$," American Journal of Physiology-Cell Physiology, vol. 280, no. 6, pp. C1588-C1598, 2001.

[78] F. Aoyama and A. Sawaguchi, "Functional transformation of gastric parietal cells and intracellular trafficking of ion channels/transporters in the apical canalicular membrane associated with acid secretion," Biological \& Pharmaceutical Bulletin, vol. 34, no. 6, pp. 813-816, 2011.

[79] G. C. Schofield, S. Ito, and R. P. Bolender, "Changes in membrane surface areas in mouse parietal cells in relation to high levels of acid secretion," Journal of Anatomy, vol. 128, no. Pt 4, pp. 669-692, 1979.

[80] A. M. Sherry, D. H. Malinowska, R. E. Morris, G. M. Ciraolo, and J. Cuppoletti, "Localization of ClC-2 Cl- channels in rabbit gastric mucosa," American Journal of Physiology-Cell Physiology, vol. 280, no. 6, pp. C1599-C1606, 2001.

[81] M. Nighot, A. Moeser, R. Ueno, and A. Blikslager, "Gastro protective properties of the novel prostone SPI-8811 against acid-injured porcine mucosa," World Journal of Gastroenterology, vol. 18, no. 34, pp. 4684-4692, 2012.

[82] M. R. Bösl, V. Stein, C. Hübner et al., "Male germ cells and photoreceptors, both dependent on close cell-cell interactions, degenerate upon $\mathrm{ClC}-2 \mathrm{Cl}-$ channel disruption," The EMBO Journal, vol. 20, no. 6, pp. 1289-1299, 2001.

[83] M. D. Parker and W. F. Boron, "The divergence, actions, roles, and relatives of sodium-coupled bicarbonate transporters," Physiological Reviews, vol. 93, no. 2, pp. 803-959, 2013.

[84] M. F. Romero, A. P. Chen, M. D. Parker, and W. F. Boron, "The SLC4 family of bicarbonate $\left(\mathrm{HCO}_{3}{ }^{-}\right)$transporters," Molecular Aspects of Medicine, vol. 34, no. 2-3, pp. 159-182, 2013.

[85] R. Chambrey, I. Kurth, J. Peti-Peterdi et al., "Renal intercalated cells are rather energized by a proton than a sodium pump," Proceedings of the National Academy of Sciences, vol. 110, no. 19, pp. 7928-7933, 2013.

[86] S. B. H. Ko, X. Luo, H. Hager et al., "AE4 is a DIDS-sensitive $\mathrm{Cl}-/ \mathrm{HCO} 3$ - exchanger in the basolateral membrane of the renal CCD and the SMG duct," American Journal of Physiology-Cell Physiology, vol. 283, no. 4, pp. C1206-C1218, 2002.

[87] G. Peña-Münzenmayer, A. T. George, G. E. Shull, J. E. Melvin, and M. A. Catalán, "Ae4 (Slc4a9) is an electroneutral monovalent cation-dependent $\mathrm{Cl}-/ \mathrm{HCO} 3-$ exchanger," The Journal of General Physiology, vol. 147, no. 5, pp. 423-436, 2016.

[88] G. Fairbanks, T. L. Steck, and D. F. H. Wallach, "Electrophoretic analysis of the major polypeptides of the human erythrocyte membrane," Biochemistry, vol. 10, no. 13, pp. 2606-2617, 1971.

[89] R. A. F. Reithmeier, "The erythrocyte anion transporter (band 3)," Current Opinion in Structural Biology, vol. 3, no. 4, pp. 515-523, 1993.

[90] R. A. Reithmeier, D. M. Lieberman, J. R. Casey et al., "Structure and function of the band $3 \mathrm{Cl} / \mathrm{HCO} 3-$ transporter," Annals of the New York Academy of Sciences, vol. 574, pp. 75-83, 1989.

[91] E. Cordat and J. R. Casey, "Bicarbonate transport in cell physiology and disease," Biochemical Journal, vol. 417, no. 2, pp. 423-439, 2009.

[92] K. E. Kudrycki, P. R. Newman, and G. E. Shull, "cDNA cloning and tissue distribution of mRNAs for two proteins that are related to the band $3 \mathrm{Cl}-\mathrm{HCO} 3$ - exchanger," The Journal of Biological Chemistry, vol. 265, no. 1, pp. 462-471, 1990.

[93] J. Medina, A. Acin, and J. Prieto, "Molecular cloning and characterization of the human AE2 anion exchanger (SLC4A2) gene," Genomics, vol. 39, no. 1, pp. 74-85, 1997.

[94] J. M. Banales, E. Sáez, M. Úriz et al., "Up-regulation of microRNA 506 leads to decreased $\mathrm{Cl}-/ \mathrm{HCO} 3-$ anion exchanger 2 expression in biliary epithelium of patients with primary biliary cirrhosis," Hepatology, vol. 56, no. 2, pp. 687-697, 2012.

[95] U. Beuers, L. Maroni, and R. O. Elferink, "The biliary HCO3umbrella," Current Opinion in Gastroenterology, vol. 28, no. 3, pp. 253-257, 2012.

[96] E. Svastova, W. Witarski, L. Csaderova et al., "Carbonic anhydrase IX interacts with bicarbonate transporters in lamellipodia and increases cell migration via its catalytic domain," Journal of Biological Chemistry, vol. 287, no. 5, pp. 3392-3402, 2012.

[97] L. R. Gawenis, C. Ledoussal, L. M. Judd et al., "Mice with a targeted disruption of the AE2 exchanger are achlorhydric," Journal of Biological Chemistry, vol. 279, no. 29, pp. 3053130539, 2004.

[98] Y. Wang, S.-F. Wu, G.-Q. Chen, and G.-H. Fu, "Effect of block deletions in the C-terminus on the functional expression of human anion exchanger 1 (AE1)," Molecular Membrane Biology, vol. 24, no. 1, pp. 65-73, 2007.

[99] W.-H. Suo, N. Zhang, P.-P. Wu et al., "Anti-tumour effects of small interfering RNA targeting anion exchanger 1 in experimental gastric cancer," British Journal of Pharmacology, vol. 165, no. 1, pp. 135-147, 2012.

[100] M. Donowitz, C. M. Tse, and D. Fuster, "SLC9/NHE gene family, a plasma membrane and organellar family of $\mathrm{Na}+/ \mathrm{H}$ + exchangers," Molecular Aspects of Medicine, vol. 34, no. 23, pp. 236-251, 2013.

[101] N. C. Zachos, M. Tse, and M. Donowitz, "Molecular physiology of intestinal $\mathrm{N}+\mathrm{H}+$ exchange," Annual Review of Physiology, vol. 67, no. 1, pp. 411-443, 2005.

[102] H. Rossmann, T. Sonnentag, A. Heinzmann et al., "Differential expression and regulation of $\mathrm{Na}+\mathrm{H}+$ exchanger isoforms in rabbit parietal and mucous cells," American Journal of Physiology-Gastrointestinal and Liver Physiology, vol. 281, no. 2, pp. G447-G458, 2001.

[103] S. Y. Loo, M. K. Chang, C. S. Chua, A. P. Kumar, S. Pervaiz, and M. V. Clement, "NHE-1: a promising target for novel anti-cancer therapeutics," Current Pharmaceutical Design, vol. 18, no. 10, pp. 1372-1382, 2012.

[104] S. J. Konturek, P. C. Konturek, T. Pawlik, Z. Sliwowski, W. Ochmanski, and E. G. Hahn, "Duodenal mucosal protection by bicarbonate secretion and its mechanisms," Journal of Physiology and Pharmacology, vol. 55, no. Suppl 2, pp. 5-17, 2004.

[105] E. Slepkov and L. Fliegel, "Structure and function of the $\mathrm{NHE} 1$ isoform of the $\mathrm{Na}+/ \mathrm{H}+$ exchanger," Biochemistry and Cell Biology, vol. 80, no. 5, pp. 499-508, 2002.

[106] Z. Wang, J. Orlowski, and G. E. Shull, "Primary structure and functional expression of a novel gastrointestinal isoform of 
the rat $\mathrm{Na} / \mathrm{H}$ exchanger," Journal of Biological Chemistry, vol. 268, no. 16, pp. 11925-11928, 1993.

[107] W. A. Hoogerwerf, S. C. Tsao, O. Devuyst et al., "NHE2 and NHE3 are human and rabbit intestinal brush-border proteins," American Journal of Physiology-Gastrointestinal and Liver Physiology, vol. 270, no. 1, pp. G29-G41, 1996.

[108] P. J. Schultheis, L. L. Clarke, P. Meneton et al., "Renal and intestinal absorptive defects in mice lacking the NHE3 $\mathrm{Na}+/$ H+ exchanger," Nature Genetics, vol. 19, no. 3, pp. 282-285, 1998.

[109] L. R. Gawenis, J. M. Greeb, V. Prasad et al., "Impaired gastric acid secretion in mice with a targeted disruption of the NHE4 $\mathrm{Na}+\mathrm{H}+$ Exchanger," Journal of Biological Chemistry, vol. 280, no. 13, pp. 12781-12789, 2005.

[110] M. M.-C. Kuo, W. J. Haynes, S. H. Loukin, C. Kung, and Y. Saimi, "Prokaryotic K+channels: from crystal structures to diversity," FEMS Microbiology Reviews, vol. 29, no. 5, pp. 961-985, 2005.

[111] H. Terlau and F. Kirchhoff, Ion Channels/Excitable Membranes, Oxford University Press, Oxford, UK, 1992.

[112] Z. A. Mccrossan and G. W. Abbott, "The MinK-related peptides," Neuropharmacology, vol. 47, no. 6, pp. 787-821, 2004.

[113] A. Fujita, Y. Horio, K. Higashi et al., "Specific localization of an inwardly rectifying $\mathrm{K}(+)$ channel, Kir4.1, at the apical membrane of rat gastric parietal cells; its possible involvement in $\mathrm{K}(+)$ recycling for the $\mathrm{H}(+)-\mathrm{K}(+)$-pump," J Physiol, vol. 540, no. Pt 1, pp. 85-92, 2002.

[114] D. H. Malinowska, A. M. Sherry, K. P. Tewari, and J. Cuppoletti, "Gastric parietal cell secretory membrane contains PKA- and acid-activated Kir2.1 K+ channels," American Journal of Physiology-Cell Physiology, vol. 286, no. 3, pp. C495-C506, 2004.

[115] P. Song, S. Groos, B. Riederer et al., "Kir4.1 channel expression is essential for parietal cell control of acid secretion," Journal of Biological Chemistry, vol. 286, no. 16, pp. 14120-14128, 2011.

[116] P. Yanglin, Z. Lina, L. Zhiguo et al., "KCNE2, a downregulated gene identified by in silico analysis, suppressed proliferation of gastric cancer cells," Cancer Lett, vol. 246, no. 1-2, pp. 129-138, 2007.

[117] C. Olivia, L. Elena, B. Luca et al., "hERG1 channels regulate VEGF-A secretion in human gastric cancer: clinicopathological correlations and therapeutical implications," Clinical Cancer Research An Official Journal of the American Association for Cancer Research, vol. 20, no. 6, pp. 1502-1512, 2014.

[118] X.-D. Shao, K.-C. Wu, X.-Z. Guo, M.-J. Xie, J. Zhang, and D.-M. Fan, "Expression and significance of HERG protein in gastric cancer," Cancer Biology \& Therapy, vol. 7, no. 1, pp. 45-50, 2008.

[119] Z. Riping, T. Pei, C. Qiang et al., "Human ether-à-go-gorelated gene expression is essential for cisplatin to induce apoptosis in human gastric cancer," Oncology Reports, vol. 27, no. 2, p. 433, 2011. 